\title{
Effect of Inoculations in Soybean [Glycine max (L) Merr.] on Productivity and Soil Properties in Soybean-Wheat System on Vertisols in Central India
}

\author{
Praveen K. Jaga ${ }^{*}$, Satish K. Sharma ${ }^{2}$ and Krishna B. Sharma ${ }^{3}$ \\ ${ }^{1}$ Department of Soil Science and Agricultural Chemistry, ${ }^{2}$ Department of Agricultural \\ Engineering, JNKVV, College of Agriculture, Ganj Basoda (Vidisha), M.P., India \\ ${ }^{3} S V$ University, Sagar (MP), India \\ *Corresponding author
}

\section{A B S T R A C T}

\section{Keywords}

Soybean, Wheat, Bio-fertilizers residual effect, Soil, Properties, Productivity

\section{Article Info}

Accepted:

28 January 2021

Available Online:

10 February 2021
A field experiments was conducted at farmer's field village basoda (Vidisha) during kharif seasons 2018-19 to study the possibility of improving the microbiological fertilizer for soybean by seed inoculation with Rhizobium and plant growth promoting rhizobacteria alone and in combination using soybean cultivar JS 95-60. Their residual contribution was assessed on productivity of succeeding wheat (Tritium aesivum L.) at three levels of $\mathrm{N}$ and soil properties. The trial was set up in randomized block design with seven treatments and four replications. Rhizobium $s p$. alone gave significant increase in nodules number (74 \%), nodules dry weight $\left(485 \mathrm{mg} /\right.$ nodules), seed yield $\left(27.5 \mathrm{qha}^{-1}\right)$ leaf area index (14.5) and harvest index $(49.5 \%)$ over the uninoculated control. The PGPR alone gave significant increase in nodule number (73.5\%), nodules dry weight (481 mg /nodules) seed yield (26.9 $\mathrm{q} \mathrm{ha}^{-1}$ ) leaf area index (14.2) and harvest index (48.9\%) over the uninoculated control. Conjoint use of Rhizobium and PGPR also result in 9.6 and $12.8 \%$ increase in soybean grain and straw yields respectively over control. It is also significantly improved available $\mathrm{N}, \mathrm{P}$ and $\mathrm{K}$ in soil by 18.756 .7 and $17.5 \%$ respectively over the uninoculated control at the harvest. In soybean crop, the N levels PGPR and Rhizobium revealed 3.88 and $3.91 \mathrm{t} \mathrm{ha}^{-1}$ wheat grain yield as compared to $3.67 \mathrm{t} \mathrm{ha}^{-1}$ with uninoculated soybean crop. Conjoint application further increased the wheat grain and straw yields by about $9.9 \%$ over the uninoculated soybean. Different inoculation treatments also significantly improved the various yield attributed of wheat. Dual inoculation of Rhizobium sp. and PGPR in soybean also significantly increased soil available $\mathrm{N}$ by $16.3 \%$ and $17.4 \%$ and soil available $\mathrm{P}$ by 27.5 and $50.0 \%$ of wheat over the uninoculated soybean respectively. Increasing levels of $\mathrm{N}$ significant increased the wheat grain and straw yields, available $\mathrm{N}, \mathrm{P}$ and $\mathrm{K}$ in soil at harvest.

\section{Introduction}

Soybean [Glycine max (L) Merr.] is known as the golden bean of the $21^{\text {st }}$ century and is one of the important legume crops of India which helps in maintaining soil fertility and rich source of protein. It has great potential as a kharif oilseed crop in Madhya Pradesh. Being a legume, Soybean is capable of fixing atmospheric nitrogen and provide itself with 
sufficient amounts of available nitrogen, which make plants a very good fit for crop rotations through symbiotic relationship with soil bacteria of genus Rhizobium sp. Seed inoculation of soybean with appropriate Rhizobium sp. at sowing is recommended for obtaining maximum performance. It has been found in different studies that a part of fixed nitrogen by legumes transfer to succeeding crop resulting in substantial $\mathrm{N}$ economy and higher productivity of cropping system (Mayer et al.2003). Residual effect of soybean crop on seceding cereals in regarding of saving of fertilizers in succeeding crops has been reported (Jaga and Jamaliaya, 2020). Since Rhizobia modulating soybean is present naturally in Indian soil and uninoculated soyabean also fixes atmospheric nitrogen and contribute to the residual effect. Application of bio-fertilizers allows successful nodulation of plants, better nitrogen fixation from the atmosphere, stimulation of plant growth and development, increase in biomass and nitrogen content in the plant, as well as yield and grain quality. Therefore it is considered as an alternative or supplement to the reduced use of chemicals in crop production.

Wheat (Tritium aesivum L.) is the second most important food grain crop in India and the requirement of nutrient of wheat crop is largely met from chemical fertilizers which account for $20.5 \%$ of total fertilizer consumption in the country (FAI, 2017). Conjoint use of Rhizobium and plant growth promoting rhizobacteria is now advocated to Rhizobia and plant growth promotion through PGPR (Chandra and Pareek, 2002; Khanna and Sharma, 2011) in pulse crop. Enhancement of nitrogen fixation by coinoculation of Rhizobia some plant growth promoting bacteria is a good way to improve $\mathrm{N}$ availability in sustainable agricultural production (Yuming et al., 2003).It seems essential to found out the contribution of Rhizobium sp. and plant growth promoting bacteria inoculation in soybean on productivity of soybean-wheat sequence and soil health. It will help in giving practical recommendation for bio-fertilizer use in soybean-wheat cropping sequence in the region in minimizing the burden of chemical fertilizers. So it is assumed that co-inoculation may exert a beneficial effect on soybean production. The main objective of this trial was to determine the effect of co-inoculation with Rhizobium and PGPR strain on productivity, yield and soil health.

\section{Materials and Methods}

Field experiments on soybean-wheat sequence were conducted during kharif seasons of 2018 and 2019 at farmer's field village basoda district Vidisha Madhya Pradesh $\left(23^{0} \quad 15^{\prime} \mathrm{N}\right.$ latitude, $77^{0} \quad 55^{\prime}$ E longitude and at $451 \mathrm{~m}$ above mean sea level). The experimental soil belongs to the order of Vertisols. The properties of the experimental soils at the initiation of the study are given in table 1. The experiment was laid out in split plot design, treatment in soybean crop consisting seed inoculation with Rhizobium $s p$. PGPR, Rhizobium + PGPR, RDF (NPK 20:60:40 kg ha-1) and uninoculated control were replicated thrice in main plots comprising 3 sub plot of $2.5 \times 4.0 \mathrm{~m}$ size. The used PGPR and Rhizobium $s p$ was obtained from bio-fertilizers unit, microbiology section, Bhopal and PAU Ludhiana respectively. Nitrogen $\mathrm{P}$ and $\mathrm{K}$ were applied at the time of sowing in the form of urea SSP and MOP respectively. The soybean crop variety was JS 95-60 and sown at a spacing of $30 \mathrm{~cm} \quad X \quad 10 \mathrm{~cm}$. Inoculation wherever required, was done as per treatments at the time of sowing through seed treatment using inoculums rate of $20 \mathrm{~g}$ inoculation $\mathrm{kg}^{-1}$ seed. Dual inoculation was done by mixing the $20 \mathrm{~g}$ inoculation $\mathrm{kg}^{-1}$ seed of each Rhizobium $s p$ and PGPR. The recommended dose of Rhizobium and PGPR as per treatment was 
first mixed in clean water to make thick slurry. This slurry was mixed with required quantity of seeds before sowing. The crop was raised with standard agronomic practices. The crop was harvested at maturity and three plots of each main plots were prepared for raising succeeding wheat (cv.HI 8759) at 3 Nitrogen levels of $50 \% 75 \%$ and $100 \%$ levels of recommended dose of $\mathrm{N}\left(120 \mathrm{~kg} \mathrm{ha}^{-1}\right)$. The nitrogen was applied through urea in three splits at sowing, tillering and heading stages. Other agronomic management practices were followed as per the standard recommendation. The crop harvested at maturity and observations on yield, straw yield and nodulation were recorded as per standard procedure. The dry weight of root nodules and plant were recorded after drying in hot air oven at $70{ }^{\circ} \mathrm{C}$ to constant weight. Growth and yield parameters were recorded at harvest by taking five random plant samples from each treatment. Crops were harvested at physiological maturity, threshold and plot wise yields were recorded soil, grain and straw samples were taken for analysis. K concentration in grain and straw was estimated after samples were digested in $\mathrm{HNO}_{3}-\mathrm{HClO}_{4}$ mixture (4:1).

Soil samples $(0-15 \mathrm{~cm})$ were collected from individual plots after harvesting of soybean crop and wheat crop. A soil samples were stored for estimation of biological properties in refrigerator and remaining part of soil was used for analysis of Organic carbon, available $\mathrm{N} \quad\left(0.32 \%\right.$ alkaline $\mathrm{KMnO}_{4}$, oxidizable $)$ available $\mathrm{P}$ and $\mathrm{K}$ were also determined using methods of Olsen et al., (1954) and Jackson (1973). The soil dehydrogenase activities as described by Cassida et al., (1964). The experimental data were statistically analyzed by applying analysis of variance and treatments were compared using standard procedure of ANOVA at 5\% level of significance (Table 1).

Results and Discussion

\section{Yield attributing characters and yields}

The Seed inoculation in soybean with Rhizobium sp. and PGPR alone and in combination improved the plant height, number of nodules and dry weight of nodules. The maximum plant height, number and weight of root nodules per plant were recorded with the application of $75 \% \mathrm{RDF}+$ Rhizobium sp. and PGPR which might be due to better root development and profuse nodulation on account of increase in the rhizobial activities in the rhizosphere under fertilizer levels especially due to increased $\mathrm{P}$ availability, which resulted in the formation of active and more number of root nodules. The results are in close agreement with the findings of Lone et al., (2009) and Mohod et al.(2010).Combined inoculation of $75 \%$ RDF + Rhizobium sp. and PGPR resulted in the highest increase in plant height, number and dry weight of nodules by $53.4,38.8$ and 42.9 $\%$ respectively, over the uninoculated control. Similar beneficial effect of Rhizobium sp. and PGPR, on nodulation and test weight have also been reported by Lone et al., (2009) and Mohod et al., (2010).in lentil, Bhatt and Chandra (2009) in chickpea and Tilak et al., (2006) in pigeon pea. Harvest Index (HI) was recorded significantly maximum $(57.5 \%)$ with $75 \%$ RDF + Rhizobium sp. and PGPR. and least $(45.5 \%)$ in control. It might be due to comparatively highest increase of grain yield than that of respective straw yield of crop. Application of $75 \% \mathrm{RDF}+$ Rhizobium sp. and PGPR was significantly higher grain yield and it was at par with $100 \%$ RDF. This might be due to balanced use of inoculation in soil which increased their availability in soil. The increment in supply of essential elements through organic and inorganic sources their availability, mobilization and influx into the plant tissues increased and thus improved growth and yield component and finally seed yield of soybean. The results are in agreements with Shinde et al., (2009). 
Maximum straw yield was obtained in $75 \%$ RDF + Rhizobium sp. and PGPR (5234 kg ha $\left.{ }^{1}\right)$. It may be due to better growth attributes. Tiwari et al., (1997) observed that the maximum straw yield of 5.94 tonnes was obtained with the application of $100 \%$ NPK + FYM $5 \mathrm{t} \mathrm{ha}^{-1}$. The $75 \% \mathrm{RDF}+$ Rhizobium sp. and PGPR treatments recorded significantly increase of $80.8 \%$ in grain and straw yield over the uninoculated control. Rhizobium sp. and PGPR alone and in combination showed marginal impact on grain and straw yields possibly due to presence of sufficient rhizobia nodulation soybean in soils as a result of its cultivation from time immemorial in the region.

The indigenous soil rhizobia might have given fierce competition to inoculated rhizobia alone to occupy the nodulation sites. However, when it was inoculated conjointly with PGPR, it allowed better nodulation and N2 fixation due to synergistic effect (Gupta, et al., 2003; Khanna and Sharma, 2011) (Table 2).

\section{Soil Properties and Fertility Status}

The higher organic $\mathrm{C}$ content was recorded in all the treatments compared to control. Treatments $75 \% \mathrm{RDF}+$ Rhizobium sp. and PGPR recorded highest organic $\mathrm{C}$ content $(6.6 \mathrm{~g} / \mathrm{kg})$ in soil after soybean harvesting than at initiation of the experiment (6.0 $\mathrm{g} / \mathrm{kg}$ ). The co-inoculation of Rhizobium sp. and PGPR showed significant increased in organic $\mathrm{C}$ content $(6.4 \mathrm{~g} / \mathrm{kg})$. It is attributed mainly due to leaf shedding habit of soybean that resulted in an increase in organic $\mathrm{C}$ in soil. It may also be due to better root growth have also been reported by Chauhan et al, (2011) in soybean-wheat crop sequence and Chandra Ramesh et al.(2019) in munbeanwheat sequence. The available $\mathrm{N}$ content of the soil after the harvest of crops increased significantly over the initial contents. The increase was maximum $\left(211.0 \mathrm{~kg} \mathrm{ha}^{-1}\right)$ in the treatment where $75 \% \mathrm{RDF}+$ Rhizobium $s p$. and PGPR were applied based on soil test values in both the crops. An increase in available $\mathrm{N}$ in soil could be ascribed to enhance $\mathrm{N}_{2}$ fixation by inoculated Rhizobium sp.in soybean crop. Rhizobium sp. and PGPR alone and in combination showed significant increase in available $\mathrm{N}$ in soil. The available $\mathrm{N}$ content was at par with the highest value in treatment $100 \%$ RDF. Similar results were also reported by Chauhan et al., (2011) in soybean-wheat crop sequence (Table 3).

The available $\mathrm{P}$ content of soil increased significantly due to solubilization of PGPR in soil. This fact is further substantiated by the observation of more available $\mathrm{P}$ in soil with PGPR alone inoculation treatment being applied PGPR was a potential P solubilizers as reported by Chandra Ramesh et al., (2019). Application of $75 \%$ RDF + Rhizobium sp. and PGPR recorded significantly higher available $\mathrm{P}$ content after soybean $\left(30.6 \mathrm{~kg} \mathrm{ha}^{-1}\right)$. The lowest value $\left(18.5 \mathrm{~kg} \mathrm{ha}^{-1}\right)$ was recorded in control plot. Similar results were also observed with wheat crop with the highest available $\mathrm{P}$ (36.6 kg ha $\mathrm{kg}^{-1}$ ) recorded in the same treatments. An increase in available $P$ in soil could be ascribed to enhance the solubility of insoluble phosphorus and additional quantity of $\mathrm{P}$ supplied by adding fertilizers by inoculated Rhizobium sp.in soybean crop.

The co-inoculation of Rhizobium $s p$. and PGPR showed significant increased in Available $\mathrm{P}$ content $\left(27.2 \mathrm{~kg} \mathrm{ha}^{-1}\right)$ in soybean crop and $\left(33.6 \mathrm{~kg} \mathrm{ha}^{-1}\right)$ in wheat cropping. These results are in close conformity with the findings of Jaga and Sharma (2015). Significant increase in the available potassium content of soil after both soybean and wheat crop over control was observed due to solubilization of potassium in soil by PGPR. The results indicated that highest available $\mathrm{K}$ 
(202.7 and $233.6 \mathrm{~kg} \mathrm{ha}^{-1}$ ) was recorded with $75 \% \mathrm{RDF}+$ Rhizobium $s p$. and PGPR while lowest in control treatment (180.6 and 202.2 $\mathrm{kg} \mathrm{ha}^{-1}$ ) and it was at par with $100 \% \mathrm{RDF}$. The higher availability of potassium in the treatments were might be due to reduction of fixation and release of $\mathrm{K}$ and direct addition of potassium to available pool of the soil
(Tendon,1987) and might be due to greater availability of these nutrients with extended root system and increased cation exchange capacity of roots. Similar results were also reported by Jaga and Sharma (2015). Rhizobium sp. and PGPR alone and in combination showed significant increase in available $\mathrm{K}$ in soil by both crop.

Table.1 Chemical soil properties of experimental site

\begin{tabular}{|c|c|}
\hline Parameters & Value \\
\hline Soil texture & Clay loam \\
\hline Soil pH & 7.8 \\
\hline $\mathrm{EC}\left(\mathrm{dSm}^{-1}\right)$ & 0.12 \\
\hline Organic $\mathrm{C}\left(\mathrm{g} \mathrm{kg}^{-1}\right)$ & 6.4 \\
\hline Available N $\left(\mathrm{kg} \mathrm{ha}^{-1}\right)$ & 297 \\
\hline Available $\mathbf{P}\left(\mathrm{kg} \mathrm{ha}^{-1}\right)$ & 18.5 \\
\hline Available k $\left(\mathrm{kg} \mathrm{ha}^{-1}\right)$ & 380 \\
\hline Mineral N $\left(\mu g^{-1}\right)$ & 52.1 \\
\hline Microbial biomass carbon $\left(\mu \mathrm{g} \mathrm{g}^{-1}\right)$ & 167.5 \\
\hline
\end{tabular}

Table. 2 Treatments influence on yield attributing characters and yields of soybean (mean of 2 years)

\begin{tabular}{|c|c|c|c|c|c|c|c|}
\hline Treatments & $\begin{array}{c}\text { Plant } \\
\text { height } \\
\text { (cm) } \\
\text { 45 DAS }\end{array}$ & $\begin{array}{c}\text { Nodule } \\
\text { (no of } \\
\text { per } \\
\text { plant) }\end{array}$ & $\begin{array}{c}\text { Nodule } \\
\text { dry weight } \\
\text { (mg plant) }\end{array}$ & $\begin{array}{c}\text { Test } \\
\text { weight } \\
(\mathbf{g})\end{array}$ & $\begin{array}{c}\text { Harvest } \\
\text { Index } \\
(\mathbf{\%})\end{array}$ & $\begin{array}{c}\text { Grain } \\
\text { yield } \\
\left(\mathbf{k g ~ h a}^{\mathbf{1}} \mathbf{)}\right.\end{array}$ & $\begin{array}{c}\text { Straw } \\
\text { yield } \\
\left(\mathbf{k g ~ h a}^{-\mathbf{1}} \mathbf{)}\right.\end{array}$ \\
\hline Control & 42.8 & 40.9 & 10.5 & 15.8 & 46.8 & 998.3 & 2894.0 \\
\hline Rhizobium sp & 57.1 & 46.5 & 117.4 & 17.0 & 51.2 & 1658.6 & 4807.6 \\
\hline PGPR & 56.3 & 45.5 & 115.7 & 16.9 & 50.7 & 1599.0 & 4798.0 \\
\hline Rhizobium sp + PGPR & 62.1 & 51.4 & 126.9 & 17.2 & 54.7 & 1715.0 & 4960.0 \\
\hline RDF 75\% + Rhizobium & 65.9 & 56.8 & 144.2 & 18.0 & 57.5 & 1807.3 & 5235.0 \\
\hline sp + PGPR & & & & & & & \\
\hline RDF 100\% & 65.2 & 56.4 & 140.9 & 17.8 & 55.1 & 1799.0 & 5218.3 \\
\hline CD at 5\% & 0.55 & 1.54 & 0.52 & 0.18 & 2.0 & 3.2 & 1.9 \\
\hline CV (\%) & 0.39 & 1.08 & 0.233 & 0.59 & 2.1 & 0.114 & 0.023 \\
\hline
\end{tabular}


Table.3 Treatments influence on soil properties and fertility status after harvesting of soybean crop (mean of 2 years)

\begin{tabular}{|c|c|c|c|c|}
\hline Treatments & $\begin{array}{c}\text { OC } \\
(\mathbf{g} / \mathbf{k g})\end{array}$ & $\begin{array}{c}\text { Available N } \\
(\mathbf{k g} / \mathbf{h a})\end{array}$ & $\begin{array}{c}\text { Available P } \\
(\mathbf{k g} / \mathbf{h a})\end{array}$ & $\begin{array}{c}\text { Available K } \\
\text { (kg/ha) }\end{array}$ \\
\hline Control & 6.03 & 191.4 & 18.5 & 180.6 \\
\hline Rhizobium sp & 6.36 & 196.5 & 22.3 & 191.6 \\
\hline PGPR & 6.26 & 195.1 & 21.4 & 190.3 \\
\hline $\begin{array}{c}\text { Rhizobium } \boldsymbol{s p}+ \\
\text { PGPR }\end{array}$ & 6.46 & 198.7 & 27.2 & 197.9 \\
\hline $\begin{array}{c}\text { RDF 75\% + } \\
\text { Rhizobium } \boldsymbol{s p}+\end{array}$ & 6.67 & 211.0 & 30.6 & 202.7 \\
\hline PGPR & & & & 200.5 \\
\hline RDF 100\% & 6.56 & 205.2 & 29.2 & 1.1 \\
\hline CD at 5\% & 0.15 & 0.88 & 0.69 & 0.32 \\
\hline CV $(\%)$ & 1.29 & 0.22 & 1.53 & \\
\hline
\end{tabular}

Table.4 Treatments influence on soil biological properties, soil health and yields of wheat crop (mean of 2 years)

\begin{tabular}{|c|c|c|c|c|c|c|c|c|}
\hline Treatments & $\begin{array}{c}\text { OC } \\
(\mathrm{g} / \mathrm{kg})\end{array}$ & $\begin{array}{c}\text { Availab } \\
\text { le N } \\
\text { (kg/ha) }\end{array}$ & $\begin{array}{c}\text { Availab } \\
\text { le P } \\
\text { (kg/ha) }\end{array}$ & $\begin{array}{c}\text { Available } \\
\text { K } \\
\text { (kg/ha) }\end{array}$ & $\begin{array}{c}\text { Dehydroge } \\
\text { nase } \\
\text { activities } \\
\left(\mu \text { g TPFg }^{-}\right. \\
{ }_{\text {soil day }}{ }^{-1)}\end{array}$ & $\begin{array}{l}\text { Microbial } \\
\text { biomass C } \\
\text { ( } \mu \mathbf{g ~ g}^{-1} \\
\text { soil) }\end{array}$ & $\begin{array}{c}\text { Grain } \\
\text { yield } \\
\left(\mathbf{k g ~ h a}^{1}\right)\end{array}$ & $\begin{array}{c}\text { Straw } \\
\text { yield } \\
\left(\mathrm{kg} \mathrm{ha}^{-1}\right)\end{array}$ \\
\hline Control & 7.3 & 194.8 & 27.3 & 202.2 & 165.4 & 234.7 & 2148.6 & 2901.0 \\
\hline Rhizobium sp & 8.2 & 222.2 & 31.2 & 223.5 & 205.6 & 344.4 & 4951.0 & 6781.0 \\
\hline PGPR & 8.0 & 220.7 & 30.3 & 221.6 & 192.9 & 340.6 & 4532.0 & 6252.0 \\
\hline $\begin{array}{l}\text { Rhizobium sp } \\
\quad \text { + PGPR }\end{array}$ & 8.4 & 223.6 & 33.6 & 230.5 & 211.6 & 349.9 & 5444.3 & 7567.0 \\
\hline $\begin{array}{l}\text { RDF } 75 \%+ \\
\text { Rhizobium sp } \\
\quad+\text { PGPR }\end{array}$ & 9.0 & 229.9 & 36.6 & 233.6 & 214.9 & 372.6 & 6348.6 & 8891.0 \\
\hline RDF $100 \%$ & 8.5 & 225.5 & 35.2 & 231.9 & 213.3 & 365.3 & 6133.0 & 8646.0 \\
\hline CD at $5 \%$ & 0.35 & 0.98 & 1.0 & 1.1 & 1.0 & 1.8 & 3.2 & 1.7 \\
\hline CV $(\%)$ & 2.3 & 0.24 & 1.8 & 0.29 & 0.30 & 0.30 & 0.037 & 0.01 \\
\hline
\end{tabular}


Fig.1 Residual effect of Rhizobium and PGPR inoculation in soybean on yields of succeeding wheat

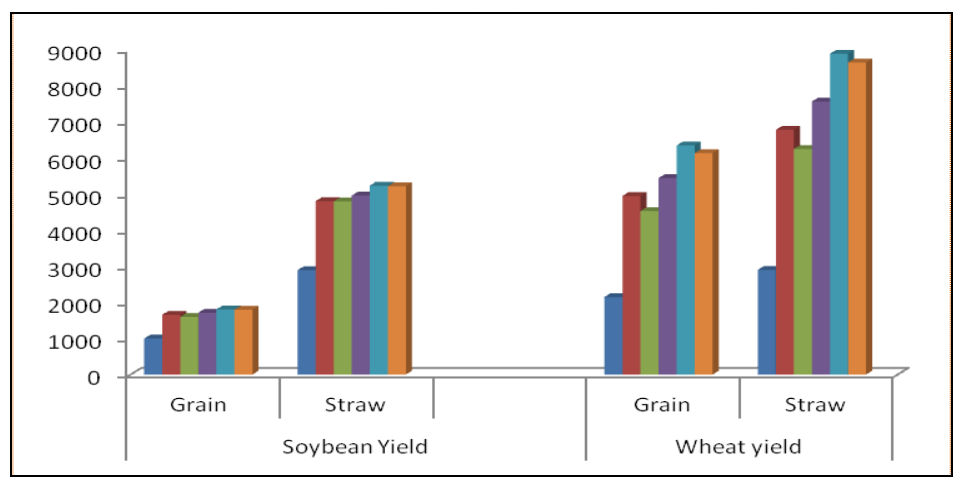

Fig.2 Residual effect of Rhizobium and PGPR inoculation in soybean on status of available nutrients of succeeding wheat

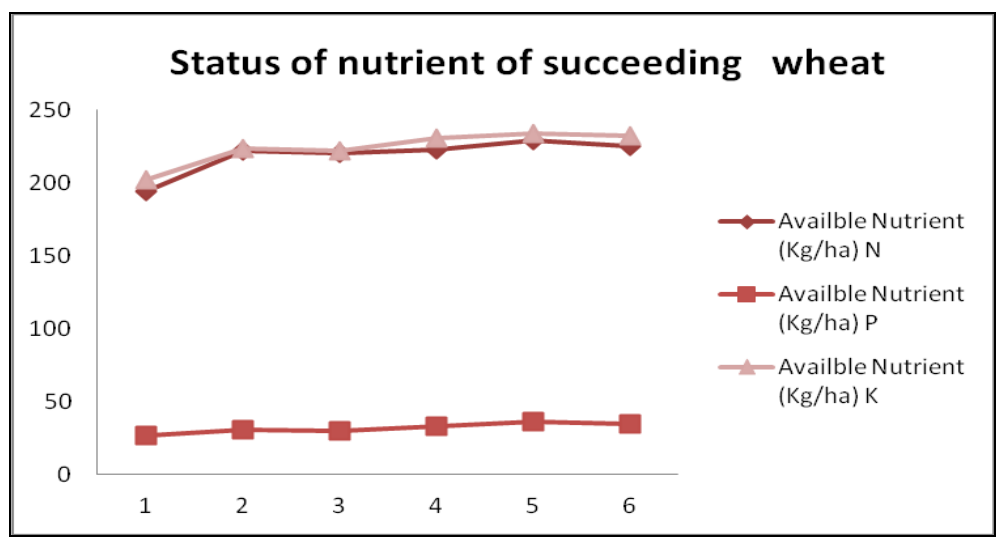

\section{Residual effect on wheat}

The different bio-fertilizer application treatments in soybean produced numerically higher grain yield and straw yield in succeeding wheat crop by $1.5 \%$ to $2.5 \%$ and 1.6 to $2.7 \%$ over uninoculated soybean (Fig. 1). The highest grain and straw yields of wheat were observed with $75 \%$ RDF + Rhizobium sp. and PGPR in soybean reported by Jaga and Sharma,(2015). Inoculation of Rhizobium sp. and PGPR alone also showed marginal residual effect by producing 3.5 and $5.6 \%$ higher wheat grain yields over the uninoculated control. The improvement on the yields after soybean and wheat could be explained in the light of inoculation treatments on various wheat yields attributes.
Although significant improvement in available NPK in soil during wheat crop following dual inoculation in soybean, this treatment did not show significant impact on wheat grain and straw yields. This may be due to high nutritional requirement and long duration crops of wheat. It is evident from data that $75 \% \mathrm{RDF}+$ Rhizobium sp. and PGPR given to wheat having previous co inoculated soybean gave grain and straw yields of wheat statistically comparable to $100 \%$ RDF. $100 \%$ RDF applied to wheat with previous co inoculated soybean gave succeeding wheat grain and straw yields equal to $75 \% \mathrm{RDF}+$ Rhizobium sp. and PGPR suggesting saving of about $25 \% \mathrm{RDF}$ in wheat through dual inoculation in preceding soybean crop. The residual effects of soybean 
on succeeding wheat crop have also been reported by Jaga and Jamliya (2020) due to increase nitrogen fixation. In the present study co inoculation of Rhizobium sp. and PGPR might have also improved BNF through synergistic interaction (Tilak et al., 2006) (Fig. 1).

\section{Soil properties}

\section{Available N P and K}

The higher available of N,P and $\mathrm{K}$ was recorded in all the treatments compared to control. Treatment $75 \% \mathrm{RDF}+$ Rhizobium $s p$. and PGPR recorded highest available $\mathrm{N}$ (229.9 kg ha $\left.{ }^{-1}\right)$, Available P (36.6 kg ha $\left.{ }^{-1}\right)$ and available $\mathrm{K}\left(233.6 \mathrm{~kg} \mathrm{ha}^{-1}\right)$ the least in control $\left(194.8 \mathrm{~kg} \mathrm{ha}^{-1}\right),\left(27.3 \mathrm{kgha}^{-1}\right)$ and $(230.0 \mathrm{~kg}$ $\mathrm{ha}^{-1}$ ) respectively. The conjoint use of Rhizobium sp. and PGPR registered significant increase of $14.9 \%$ in available $\mathrm{N}$ and $23.0 \%$ in available $\mathrm{P}$ and $13.8 \%$ available $\mathrm{K}$ in soil of wheat crop. The increase in available $\mathrm{N}, \mathrm{P}$ and $\mathrm{K}$ in soil were also observed following Rhizobium sp. and PGPR alone inoculation. It is well known that pulse crops contribute nitrogen for succeeding cereal crop because of their inherent capacity of $\mathrm{N}$ status soybean inoculated with Rhizobium sp. alone and along with PGPR depleted less $\mathrm{N}$, in soil.

The positive effect of inoculation on available $\mathrm{N}$, in soil during wheat crop is attributed to left over $\mathrm{N}, \mathrm{P}$ and $\mathrm{K}$ at soybean harvesting and release of $\mathrm{N}$ through mineralization of soybean residue in soil, being added through leaf fall and left over crop roots (Ghosh et al., 2007). This reality is substantiated by the observation of slightly higher organic matter in soil in inoculated than uninoculated soybean after harvesting. Increase in available $\mathrm{P}$ in soil in wheat crop might be due to solubilization of applied and native $\mathrm{P}$ in soil by the inoculated PGPR. These findings corroborate with those of Souza et al., (2015) and Gopalkrishnan et al., (2015) (Fig. 2).

\section{Soil biological properties}

Based on the observed effects of co inoculation; better results were achieved significantly with dehydrogenase activity in soil of 24.0 to $29.7 \%$ in wheat in comparison to the control and highest being with $75 \%$ $\mathrm{RDF}+$ Rhizobium sp. and PGPR and it was at par with $100 \%$ RDF. Rhizobium sp. and PGPR alone and in combination showed significant increase in dehydrogenase activity in soil of 16.3 and $27.8 \%$ in comparison to the control in soil by both crop. It could be attributed to increase in microbial biomass $\mathrm{C}$ in soil which led to increase in microbial activities. This positive impact was also reported by Prasanna et al., (2003). Application of $75 \%$ RDF + Rhizobium sp. and PGPR significantly increased the microbial biomass $\mathrm{C}$ in soil due to different inoculation treatment in soybean more by 47.0 to $58.9 \%$ in comparison to the control in succeeding wheat crop (Table 4). Rhizobium sp. (47.0\%) alone and PGPR depleted less $(45.3 \%)$ in soil showing reduction in microbial biomass $\mathrm{C}$ and in combination showed significant increase in microbial biomass $\mathrm{C}$ in soil in comparison to the control by both crop. These results are in agreement with report of Chandra Ramesh et al., (2019).

In conclusions the study clearly indicated that combined inoculation of $75 \% \mathrm{RDF}+$ Rhizobium sp. and PGPR in soybean crop significantly increased soybean productivity and residual soil fertility status of the Vertisols and can be used to boost up the production of soybean crop and saves approximately $25 \%$ inorganic fertilizers. The best effect on yield, soil health and soil biological properties was achieved by single inoculation, while co inoculation had a better effect on the number of microorganism, 
dehydrogenase activity and yield of soybean. All treatment had a positive effect on soybean yield, while the largest increase was obtained by co-inoculation with mineral fertilizers. Replacement of mineral fertilizers with microbial fertilizers is well justified from the perspective of energy, economy and their application enables the production of high organic food.

\section{References}

Bhatt,P. and Chandra, R. (2009) Interaction of Mesorhizobium ciceri and rhizospheric bacteria on nodulation, growth and yield of chickpea. Journal of Food Legume 22: 137-139.

Casida, Jr.L.E., Klein, D.A. and Santoro, T. (1964) Soil dehydrogenase activity. Soil Science 98, 371-376.

Chandra, R. and Pareek, R.P. (2002). Effect of rhizobacteria in urdbean and lentil. Indian Journal of Pulses Research 15 152-155.

Chauhan, S.S., Kumar, Vipin, Bhadauria, U.P.S and Dwivedi, A.K. (2011) Effect of conjoint use of organic and inorganic fertilizer on soil fertility and productivity of soybean-wheat sequence. Annals of Plant and Soil Research 13(1):47-50

FAI (Fertilizer Association of India) (2017) Fertilizer Statistics 2016-17. The Fertilizer Association of India, New Delhi

Ghos, P.K., Bandyopadhyay, K.K., Wanjary, R.H., Manna, M.C., Mishra, A.K. Mohanty, M. and Rao, A.S. (2007) Legume effect for enhancing productivity and nutrient use efficiency in major cropping system-An Indian prospective: A review. Journal of sustainable Agriculture 30: 59-86.

Gopalkrishnan, S., Sathya, A., Vijayabharathi, R., Varshney, R.K., Gowda, C.L.L. and Krishnamurthy, L. (2015) Plant growth promoting rhizobia: challenges and Opportunities. 3Biotech 5: 355-377.

Gupta, A., Saxena, A.K., Maruli, G. and Tilak, K.V.B.R. (2003) Effect of coinoculation of PGPR and Bradyrhiziobium Sp. on the growth and yield of green gram. Tropical Agriculture 80:28-35.

Jackson, M.L. (1973) Soil Chemical Analysis, Prinice Hall Inc. England Cliffs, New Jersey.

Jaga, P.K. and Sharma Satish (2015). Effect of bio-fertilizer and fertilizers on productivity of Soybean. Annals of Plant and Soil Research 17(2): 171-174.

Jaga, P.K., and Jamliya, G.S. (2020) Nutrient management productivity and its balance in soybean-wheat copping in Vindhyan plateau of M.P. India.

Jaga, Praveen, K. and Jamliya, G.S. (2020). Nutrient management productivity and its balance in Soybean (Glycine Max (L.)Merrill) Wheat (Triticum aestivum) cropping in Vindhyan Plateau of M.P., India. Int.J.Curr.Microbiol.App.Sci. 9(02): 641-651.

Khanna, V. and Sharma, P. (2011) Potential for enhancing lentil (Lens culinaris) productivity by co-inoculation with PSB, plant growth promoting rhizobacteria and Rhizobium. Indian Journal of Agricultural Sciences, 81 932-934

Mayer, J., Buegger, F., Jensen, E.S., Schloter M. and Heb, J. (2003) Residual nitrogen contribution from grain legumes to succeeding wheat and rape and related microbial process. Plant and soil 255, 541-554.

Lone, Bilal Ahemed, Husan, Badrul, Ansar, S. and Singh, Amarjeet (2009) effect of seed rate, raw spacing and fertility levels on growth and nutrient uptake of soybean under temperature conditions. Journal of Agricultural and Biological Science 4 (3):7-10. 
Mohad, N.B., Nimade Seema, Ghadage, Preeti (2010) Effect of INM on growth and yield parameters of soybean. Green Farming 1(3): 270-271.

Olsen, S.R., Cole, C.V., Watanabe, F.S. and Dean, L.A. (1954) Estimation of available-P in soil by extraction with $\mathrm{NaHCO}_{3}$. United States Department of Agricultural Circular, 939:1-9.

Prasanna, R., Tripathi, U., Dominic, T.R., Singh, A.K., Yadav, A and Singh, P.K. (2003) An improvised technique for measurement of nitrogen fixation by blue green algae and Azolla using intact soil cores. Experimental Agriculture 39: $145-150$

Ramesh Chandra, Neha Pareek, Navneet, and Raverkar, K.P. (2019) Effect of Rhizobium and PGPR inoculation in Mungbean on productivity and soil properties in mungbean-wheat sequence. Journal of Indian Society of soil science 67 (4): 458-464.

Shinde,P.S., Sanlpal, V.Y., Jawale, S.M., Shaikh, A.A., Dalavi, N.D. and Jadhav, M.B. (2009) Effect of INM on yield attributes and quality of soybean. Journal of Maharashtra Agricultural
Universities 34(1): 107-108.

Souza, R., Ambrosini, A. and Passaglia, L.M. (2015) Plant growth promoting bacteria as inoculants in agricultural soils. Genetics and molecular Biology 38:401-419.

Tandon, H.L.S. (1987) Phosphorus Research and Agricultural Production in India. FDCO, New Delhi.

Tilak, K.V.B.R., Nandanavanam, R. and Manoharachari, C. (2006) Synergistic effects of plant-growth promoting rhizobacteria and Rhizobium on nodulation and nitrogen fixation by pigeon pea. European journal of Soil Science 57: 67-71.

Tiwari, Alok, Sharma, S.K., Shrivastava, S.P. and Tambhare, B.R. (1997) Study of plant physiological growth parameters and yield of soybean under the influence of manure and fertilizer. $A d v$. Pl. Sci.10 (1): 149-152.

Yuming, B., Xiomin, Z. and Smith, D.L. (2003) Enhanced soybean plant growth resulting from co-inoculation of Bacillus strains of Brady Japonicum. Crop Science, 43:1774-1778.

\section{How to cite this article:}

Praveen K. Jaga, Satish K. Sharma and Krishna B. Sharma. 2021. Effect of Inoculations in Soybean [Glycine $\max$ (L) Merr.] on Productivity and Soil Properties in Soybean-Wheat System on Vertisols in Central India. Int.J.Curr.Microbiol.App.Sci. 10(02): 3520-3529. doi: https://doi.org/10.20546/ijcmas.2021.1002.387 